Tero Erkkilä

\title{
Transparency and Nordic Openness in Finland: Ideational Shift, Invented Tradition, and Anders Chydenius
}

\section{Introduction}

Information access laws have spread rapidly since the 1990s primarily as part of the global drive for good governance, and also due to national political context and conflicts. ${ }^{1}$ Transparency has become one of the key concepts of contemporary politics. ${ }^{2}$ It is a new term in the political language of the Anglo-American world and beyond, and there are, in addition, liberal market notions bound up with the term that have made their way into national political contexts. This is perhaps most apparent in developing countries that are dependent on foreign direct investment and development aid. ${ }^{3}$ But countries with a significant institutional history of openness, such as the Nordic countries, are also exposed to the new connotations of transparency. ${ }^{4}$

International policy discourses often tend to take nationalistic forms. ${ }^{5}$ While an analysis of all national variants of the debate in the Nordic countries is beyond the scope of this chapter, the Finnish discourse on Nordic openness is one example of this. It constructs a nationalistic, collective positioning of

1 Daniel Berliner, “The Political Origins of Transparency,” The Journal of Politics 76, no. 02 (April 2014): 479-91, doi:10.1017/S0022381613001412; Christopher Hood, "Transparency in Historical Perspective," in Transparency: The Key to Better Governance?, ed. David Heald and Christopher C. Hood (Oxford: Oxford University Press, 2006), 3-23.

2 Todd Sanders and Harry G. West, "Power Revealed and Concealed in the New World Order," in Transparency and Conspiracy: Ethnographies of Suspicion in the New World Order, ed. Todd Sanders and Harry G. West (Durham: Duke University Press, 2003).

3 Abraham Azubuike, "Accessibility of Government Information as a Determinant of Inward Foreign Direct Investment in Africa," in Best Practices in Government Information: A Global Perspective, ed. Irina Lynden and Jane Wu (München: K.G. Saur, 2008), 243; Jeannine E. Relly and Meghna Sabharwal, "Perceptions of Transparency of Government Policymaking: A Cross-National Study," Government Information Quarterly 26, no. 1 (2009): 148-57, doi:10.1016/ j.giq.2008.04.002.

4 Erkkilä, Government Transparency: Impacts and Unintended Consequences (Houndmills: Palgrave Macmillan, 2012).

5 Vivien A. Schmidt, The Futures of European Capitalism (Oxford: Oxford University Press, 2002), 211.

Ә OpenAccess. () 2022 Tero Erkkilä, published by De Gruyter. (cc)BY This work is licensed under the Creative Commons Attribution 4.0 International License. https://doi.org/10.1515/9783110730104-008 
Finns as members of an open Nordic society at the top of global economic competition. This chapter analyses the historical tradition of institutional openness in Finland. I will argue that there is an increasing awareness of this tradition, apparent in policy discourse on "Nordic openness," which portrays openness and access to government information as distinctive characteristics of Finland. ${ }^{6}$ While openness is usually linked with the consensual tradition of governing typical for the Nordic countries, ${ }^{7}$ awareness of this globally distinctive tradition also results from reflexivity over institutional history that is seen to provide advantage in global economic competition. ${ }^{8}$ Global rankings and indicators that measure the performance of states in regard to good governance associate transparency with economic competitiveness. The Nordic countries have fared well in these rankings.

The public sphere has been a central element in studies of nation building, and has been used to explain the contextual differences of collective identities, nationhood, and nationalism. ${ }^{9}$ In a world where convergence is seen to occur via grand processes such as "modernisation" and "globalisation," there are still differing national trajectories in political and economic institutions, concerning citizen rights and freedoms, as well as "us vs. them" narratives of nationhood. The public sphere has been theorised as both a structure or as a discursive space. ${ }^{10}$ The latter position marks an opening for a genealogical conceptual analysis of the "public," an approach which is also adopted in this text. This approach makes concepts such as "publicity," "openness," and "transparency" instrumental in defining the institutional boundaries of the public sphere. ${ }^{11}$ As a

6 Tero Erkkilä, Government Transparency: Impacts and Unintended Consequences.

7 Pekka Kettunen and Markku Kiviniemi, "Policy-Making in Finland: Consensus and Change," in The Work of Policy - an International Survey, ed. Hal Colebatch (New York: Lexington Books, 2006), 147-60; Johanna Rainio-Niemi, "Small State Cultures of Consensus: State Traditions and Consensus-Seeking in the Neo-Corporatist and Neutral Policies in Post-1945 Austria and Finland" (Dissertation, Department of Social Science History, University of Helsinki, 2008).

8 Douglass C. North, Institutions, Institutional Change and Economic Performance (Cambridge: Cambridge University Press, 1990).

9 Klaus Eder, “The Public Sphere," Theory, Culture \& Society 23, no. 2-3 (2006): 607-11, doi:10.1177/0263276406062705; Shmuel Eisenstadt and Wolfgang Schluchter, "Introduction: Paths to Early Modernities - A Comparative View," in Public Spheres and Collective Identities, ed. Shmuel N. Eisenstadt, Wolfgang Schluchter, and Bjorn Wittrock (New Brunswick: Transaction Publishers, 2001).

10 Eder, "The Public Sphere"; Myra Marx Ferree et al., "Four Models of the Public Sphere in Modern Democracies,” Theory and Society 31, no. 3 (June 2002): 289-24.

11 Cf. Margaret R. Somers, "What's Political or Cultural about Political Culture and the Public Sphere? Toward an Historical Sociology of Concept Formation," Sociological Theory 13, no. 2 
social structure, the public sphere is itself a subject of an institutionalisation process, where structural, institutional, and cultural factors meet. ${ }^{12}$

Sweden became the first country to adopt a law granting access to government information in 1766. Publicity in state affairs was debated elsewhere in eighteenth-century Europe, where accounts of failed attempts at breaking absolutist secrecy tend to follow a narrative of how Enlightenment ideas on free speech and freedom of the press battled the "mystery of the state" in vain. ${ }^{13}$ There are general features in the adoption - and non-adoption - of access laws in the 20th century, ${ }^{14}$ but the country-specific studies stress historical explanations owing mainly to local conditions. ${ }^{15}$

(1995): 113-44; Margaret R. Somers, "Let Them Eat Social Capital: Socializing the Market versus Marketizing the Social,” Thesis Eleven 81, no. 1 (2005): 5-19, doi:10.1177/0725513605051611.

12 Eder, "The Public Sphere"; Eisenstadt and Schluchter, "Introduction: Paths to Early Modernities - A Comparative View," 17-18; Margaret R. Somers, "Citizenship and the Place of the Public Sphere: Law, Community, and Political Culture in the Transition to Democracy," American Sociological Review 58, no. 5 (1993): 587-620.

13 Richard van Dülmen, Die Gesellschaft Der Aufklärer: Zur Bürgerlichen Emanzipation Und Aufklärerischen Kultur in Deutschland. (Frankfurt am Main: Fischer Taschenbuch Verlag, 1986); Joris van Eijnatten, "Between Practice and Principle: Dutch Ideas on Censorship and Press Freedom, 1579-1795," Redescriptions: Yearbook of Political Thought and Conceptual History 8 (2004): 85113; Andreas Gestrich, Absolutismus Und Öffentlichkeit: Politische Kommunikation in Deutschland Zu Beginn Des 18. Jahrhunderts (Göttingen: Vandenhoeck \& Ruprecht, 1994); Tim Knudsen, Offentlighed i Det Offentlige. Om Historiens Magt (Aarhus: Aarhus Universitetsforlag, 2003); Timo Konstari, Asiakirjajulkisuudesta Hallinnossa. Tutkimus Yleisten Asiakirjain Julkisuudesta Hallinnon Kontrollivälineenä (Helsinki: Suomalainen lakimiesyhdistys, 1977); Wolfgang Martens, Die Botschaft Der Tugend: Die Aufklärung Im Spiegel Der Deutschen Moralischen Wochenschriften (Stuttgart: Metzler, 1971); Andreas Würgler, “Conspiracy and Denunciation: A Local Affair and Its European Publics (Bern, 1749)," in Cultures of Communication from Reformation to Enlightenment: Constructing Publics in the Early Modern German Lands, ed. James Van Horn Melton (Aldershot: Ashgate Pub Ltd, 2002), 119-131.

14 Colin J. Bennett, "Understanding Ripple Effects: The Cross-National Adoption of Policy Instruments for Bureaucratic Accountability,” Governance 10, no. 3 (1997): 213-33, doi:10.1111/ 0952-1895.401997040.

15 John Durham Peters, Courting the Abyss: Free Speech and the Liberal Tradition, 1st ed. (Chicago: University of Chicago Press, 2005); Tore Grønlie and Anne-Hilde Nagel, "Administrative History in Norway,” Jahrbuch Für Europäische Verwaltungsgeschichte 10 (1998): 307-32; Isabelle Häner, Öffentlichkeit Und Verwaltung (Zürich: Schulthess Polygraphisher Verlag, 1990); Knudsen, Offentlighed i Det Offentlige: Om Historiens Magt; Konstari, Asiakirjajulkisuudesta Hallinnossa: Tutkimus Yleisten Asiakirjain Julkisuudesta Hallinnon Kontrollivälineenä; Barry Owen, "France," in Comparative Public Administration, ed. J. A. Chandler (London: Routledge, 2000), 200; K. G. Robertson, Public Secrets: A Study in the Development of Government Secrecy (New York: St. Martin's Press, 1982); Susan Rose-Ackerman, From Elections to Democracy: Building Accountable Government in Hungary and Poland (New York: Cambridge University Press, 2005); Spence, 
There has been a distinctive historical trajectory in the Nordic countries, ${ }^{16}$ where access to government documents is a constitutional principle of governance, namely the "principle of publicity" (Swedish: "offentlighetsprincipen," Finnish: "julkisuusperiaate"). In Finland, the principle of publicity gained legal status in an access law adopted in $1951 .{ }^{17}$ Acknowledged as a constitutional right, the principle of publicity declares all government documents to be public unless otherwise indicated: "[D]ocuments and recordings in the possession of the public authorities are public, unless their publication has for compelling reasons been specifically restricted by an Act." ${ }^{18}$ The principle is conceptually broader than mere public access to official documents, as it is often seen to cover openness of government activities and public access to court rooms and decision-making venues.

The issue of institutional openness was debated in Denmark on various occasions from the mid-1800s onwards. For example, the freedom of the press was debated in the early 1770 s leading to a short era of liberalisation, but this freedom did not acquire a similar kind of institutional status as in Sweden and did not lead to the breaking of administrative secrecy. ${ }^{19}$ In Norway, then part of Denmark, efforts to break absolutist secrecy had a similar fate. The issue of institutional openness was debated on several occasions from the mid-1800s onwards, but it was not until 1970 that Denmark and Norway gained access legislation. In Norway, this was part of a larger process towards the democratisation of public administration. $^{20}$

\footnotetext{
"Italy," in Comparative Public Administration, ed. J. A. Chandler, 1st ed. (London: Routledge, 2000), 126 - 47; A. P. Tant, British Government: The Triumph of Elitism: A Study of the British Political Tradition and Its Major Challenges (Aldershot: Dartmouth, 1993); Richard C. Thurlow, The Secret State: British Internal Security in the Twentieth Century (Oxford: Blackwell, 1994).

16 Carol Harlow, "Global Administrative Law: The Quest for Principles and Values," The European Journal of International Law 17, no. 1 (2006): 193.

17 Finland as a former part of Sweden had a Swedish administrative model that mostly remained intact over the period of Russian rule, 1809-1917. Konstari, Asiakirjajulkisuudesta Hallinnossa: Tutkimus Yleisten Asiakirjain Julkisuudesta Hallinnon Kontrollivälineenä; Seppo Tiihonen, Herruus: Ruotsi ja Venäjä (Helsinki: Hallintohistoriakomitea, 1994), 6.

18 Finnish Const. 731/1999, 12 §.

19 Knudsen, Offentlighed i Det Offentlige: Om Historiens Magt, 69-82.

20 Einar Høgetveit, Hvor Hemmelig? Offentlighetsprinsippet i Norge Og USA, Særlig Med Henblikk På Militærpolitiske Spørsmål. (Oslo: Pax Forlag, 1981), 70; Grønlie and Nagel, “Administrative History in Norway,” 308, 329.
} 
The issue of access to government information became topical in $18^{\text {th }}$-century Sweden amid a transition from absolutist to liberal-bourgeois rule. ${ }^{21}$ Jürgen Habermas's work on the structural transformations of the public sphere has been used to explain the institutional developments that made government information public in Sweden. ${ }^{22}$ Yet the anti-religious emphasis of this narrative is misinformed in this context, for the clergy was responsible for spreading the ideas of the Enlightenment, as well as demanding information on state affairs. $^{23}$

Indeed, it was the Ostrobothnian clergyman and representative in the Swedish Diet Anders Chydenius who is often credited with initiating the legislation in 1766. Chydenius was active in social issues and published widely. ${ }^{24}$ He has been seen as one of the forefathers of state theoretical thinking in Finland ${ }^{25}$ and there is now increasing interest in his work. But often works on older historical periods tell us more about the time in which we live than the time we study. I will show how Anders Chydenius's persona became drawn into the debates on Nordic openness and why he has become such an appealing figure at this time.

21 Knudsen, Offentlighed i Det Offentlige: Om Historiens Magt, 63; Konstari, Asiakirjajulkisuudesta Hallinnossa: Tutkimus Yleisten Asiakirjain Julkisuudesta Hallinnon Kontrollivälineenä; Perry Anderson, Lineages of the Absolutist State (London: Verso, 1993), 190 -91; Tiihonen, Herruus: Ruotsi ja Venäjä, 57.

22 Cf. Jürgen Habermas, The Structural Transformation of the Public Sphere: An Inquiry into a Category of Bourgeois Society (London: Polity Press, 1989); Knudsen, Offentlighed i Det Offentlige: Om Historiens Magt, 63; Konstari, Asiakirjajulkisuudesta Hallinnossa: Tutkimus Yleisten Asiakirjain Julkisuudesta Hallinnon Kontrollivälineenä.

23 There are also other historical cases, often disregarded in the analysis of the "historical publics," where religion and science provided both topics and forums for public debates. Marc Forster, "Debating the Meaning of Pilgrimage: Maria Steinbach 1733," in Cultures of Communication from Reformation to Enlightenment: Constructing Publics in the Early Modern German Lands, ed. James Van Horn Melton (Aldershot: Ashgate Pub Ltd, 2002); Robert von Friedeburg, "The Public of Confessional Identity: Territorial Church and Church Discipline in 18th-Century Hesse," in Cultures of Communication from Reformation to Enlightenment: Constructing Publics in the Early Modern German Lands, ed. James Van Horn Melton (Aldershot: Ashgate Pub Ltd, 2002), 93103; David Zaret, "Religion, Science, and Printing in the Public Spheres in Seventeenth-Century England," in Habermas and the Public Sphere, ed. Craig Calhoun (Cambridge: The MIT Press, 1992).

24 Jyrki Käkönen, “Anders Chydenius Ja 1700-Luvun Suomalainen Valtio-Opillinen Ajattelu,” in Valtio Ja Yhteiskunta. Tutkielmia Suomalaisen Valtiollisen Ajattelun Ja Valtio-Opin Historiasta., ed. Jaakko Nousiainen and Dag Anckar (Juva: Werner Söderström, 1983), 42-43; Juha Manninen, "Anders Chydenius and the Origins of World's First Freedom of Information Act," in The World's First Freedom of Information Act. Anders Chydenius' Legacy Today, ed. Anders Chydenius Foundation (Kokkola: Anders Chydenius Foundation, 2006), 18-53.

25 Käkönen, “Anders Chydenius Ja 1700-Luvun Suomalainen Valtio-Opillinen Ajattelu. 
The term "transparent," originally of Latin origin (Latin: transpärēnt-em, French: transparent), has optical connotations, referring to the way light or images travel through material, allowing one to see objects on the other side. The term "transparent" has come into the English language through French and has attained remarkable international attention in recent debates on power and society. ${ }^{26}$ In contemporary political vocabulary, transparency usually has connotations of openness and clarity in political and administrative processes. But it is increasingly also regarded as an economic virtue, ${ }^{27}$ owing to paradigm shifts in information economics that largely embody the efficiency-laden virtues of good governance. $^{28}$

The notion of the virtuous circle is often used when referring to economic competitiveness resulting from tightly interlinked institutional developments. ${ }^{29}$ The OECD and the World Bank have promoted openness and access to government information as part of their policies on good governance since the mid1990s. ${ }^{30}$ There are also global rankings and indicators measuring the state of transparency in nation states. These policy instruments have been effective in formulating policy prescriptions on transparency that now link the issue to economic competitiveness. In Finland, institutional openness is seen as an advantage in global economic competition. Here the accounts of Nordic openness serve as an invented tradition that helps to address future challenges related to economic globalisation. ${ }^{31}$ As I will show in the analysis, institutional openness is now seen as an element of "virtuous circles," where several institutional and contextual factors reinforce each other to grant some nations economic advantage over others.

26 Hood, "Transparency in Historical Perspective."

27 Erkkilä, Government Transparency: Impacts and Unintended Consequences.

28 Wolfgang Drechsler, "Governance, Good Governance, and Government: The Case for Estonian Administrative Capacity," TRAMES, no. 4 (2004): 388-96; Joseph Stiglitz, "Information and the Change in the Paradigm in Economics," American Economic Review, 92, no. 3 (2002): 460 501; Joseph Stiglitz, "Is There a Post-Washington Consensus Consensus?," in The Washington Consensus Reconsidered: Towards a New Global Governance, ed. Serra and Joseph Stiglitz (Oxford: Oxford University Press, 2008), 41-56.

29 Geoffrey Garrett, "Global Markets and National Politics: Collision Course or Virtuous Circle?,” International Organization, 52, no. 4 (1998): 787-824.

30 OECD, Open Government: Fostering Dialogue with Civil Society (Paris: OECD, 2003); Catherine Weaver and Christian Peratsakis, "Engineering Policy Norm Implementation: The World Bank's Transparency Transformation," in Implementation and World Politics: How International Norms Change Practice, ed. Alexander Betts and Phil Orchard (Oxford: Oxford University Press, 2014), $179-94$.

31 Erkkilä, Government Transparency: Impacts and Unintended Consequences; Hobsbawm, "Introduction: Inventing Traditions." 
Kettunen has referred to this discourse of national competitiveness as a "coercive circle" that diminishes the sphere of politics and democracy. ${ }^{32}$ Erkkilä and Piironen assess similar potentials in global country rankings, using the Weberian term "iron cage." They argue that by quantifying the criteria of "good governance" the governance indicators have the potential to limit the sphere of politics and ethics. ${ }^{33}$ Ironically, the policy of "virtuous circles" has long been seen as a normative standard for the Nordic countries, ${ }^{34}$ emphasising the values of efficiency, solidarity, and equality, and binding together economics, politics, and ethics. ${ }^{35}$ This normative ideal was based on the perception that economic growth, widening democracy and increased equality were mutually reinforcing, rather than working in opposite directions. The Nordic countries grew to depend largely on exports, which was balanced with planning, the welfare state, and labour market policies, premised on the broad inclusion of actors. ${ }^{36}$ These institutional practices also hinge on the Nordic openness of governing and access to government information.

Though openness is at present discussed as a tradition of Nordic governing, there is an apparent conceptual reframing of institutional practices in Finland. There is a distinctive institutional trajectory towards openness and access to government information in the Nordic countries, linked to democracy and political accountability. However, current awareness of this tradition is linked to a global drive for transparency where access to government information is seen as an attribute of economic competitiveness. This also concerns the historical roots of institutional openness that is now seen to bring a competitive advantage to Finland. While access to government information has traditionally been discussed under the concept of publicity, belonging to the semantic field of democracy,

32 Kettunen, Globalisaatio ja Kansallinen Me: Kansallisen Katseen Historiallinen Kritiikki, 12. 33 Tero Erkkilä and Ossi Piironen, "Politics and Numbers: The Iron Cage of Governance Indices," in Ethics and Integrity of Public Administration: Concepts and Cases, ed. Raymond W. Cox III (Armonk: ME Sharpe, 2009), 125-45; cf. Max Weber, Economy and Society, vols. 1 and 2, (Berkeley: University of California Press, 1978).

34 Kettunen, Globalisaatio ja Kansallinen Me: Kansallisen Katseen Historiallinen Kritiikki, 142-45; Pauli Kettunen, "The Society of Virtuous Circles," in Models, Modernity and the Myrdals., ed. Hanna Eskola and Pauli Kettunen, Renvall Institute Publications 8 (Helsinki: Helsinki University, 1997).

35 Pauli Kettunen, “The Nordic Model and the Making of the Competitive 'Us,"” in The Global Economy, National States and the Regulation of Labour., ed. Paul Edwards and Tony Elger (London: Mansell Publishing, 1999), 123; Paula Tiihonen, "Good Governance and Corruption in Finland," in The History of Corruption in Central Government, ed. Seppo Tiihonen (Amsterdam: IOS Press, 2003), 99-118.

36 Kettunen, "The Nordic Model and the Making of the Competitive 'Us," 129. 
there has been a shift towards notions of openness and transparency, carrying connotations of trust and economy. These ideational shifts come about with the help of an invented tradition ${ }^{37}$ that now also includes a historical reading of Anders Chydenius, who is often regarded as the father of the world's first information access law, passed in Sweden in 1766.

Analysing these changes in Finland, I will show how the discourse on Nordic openness emerged in the mid-1990s during a critical juncture for Finnish governance, due to economic crisis, intensifying economic globalisation, and Finland's accession to the EU. In explaining the rise of the policy discourse of Nordic openness and its communicative and coordinative forms, I will build on the work of Pauli Kettunen, Martin Marcussen, and Vivien Schmidt. ${ }^{38}$ In assessing the conceptual shifts and the political use of concepts, I refer to the work of Reinhart Koselleck and Quentin Skinner. ${ }^{39}$

I will first analyse the conceptual changes in governance discourse, using government platforms and selected publications of the Economic Council of Finland as my sources. I will then explore the communicative aspects of the policy discourse and the construction of a collective memory of Nordic openness in Finland in the historical accounts of the mid-2000s, when openness was also a theme for the Finnish EU Presidency (2006). I conclude that the "virtues" of good governance that are circulating internationally are now seen to have historical reference points in Finnish policy discourse, portraying Anders Chydenius as the forebear of openness in Finland. Yet, the cognitive aspects of this discourse point to political innovation and reassessments of institutional openness as an element of economic competitiveness.

37 Eric Hobsbawm, "Introduction: Inventing Traditions," in The Invention of Tradition, ed. Eric Hobsbawm and Terence Ranger (Cambridge: Cambridge University Press, 1987), 1-14.

38 Pauli Kettunen, Globalisaatio ja Kansallinen Me: Kansallisen Katseen Historiallinen Kritiikki (Tampere: Vastapaino, 2008); Martin Marcussen, Ideas and Elites: The Social Construction of Economic and Monetary Union (Aalborg: Aalborg University Press, 2000); Schmidt, The Futures of European Capitalism; Vivien A. Schmidt, "Discursive Institutionalism: The Explanatory Power of Ideas and Discourse,” Annual Review of Political Science 11, no. 1 (2008): 303-26, doi:10.1146/annurev.polisci.11.060606.135342.

39 Reinhart Koselleck, Futures Past: On the Semantics of Historical Time (New York: Columbia University Press, 2004); Quentin Skinner, "Meaning and Understanding in the History of Ideas," History and Theory 8, no. 1 (1969): 3-53; Quentin Skinner, "Language and Political Change," in Political Innovation and Conceptual Change, ed. Terence Ball, James Farr, and Russell L. Hanson (Cambridge: Cambridge University Press, 1989), 6-23. 


\section{Nordic Openness in Finland: Conceptual Change and Political Innovation}

The invented tradition and discourse of Nordic openness carries nationalistic connotations depicting Finland as a particularly open Nordic society and a league table winner in the global rankings. These rankings have been a source of national pride in Finland, constructing an image of a particularly open and successful nation. The construction of a notion of a competitive "us" 40 becomes effective through "subjectification," where actors acquire patterns of identities linked to proposed actions to maintain "our national competitiveness". ${ }^{41}$ Below, I show how the economic understanding of openness and access to government information have been acknowledged in government platforms in Finland, visible also in the conceptual shift from "publicity" to "openness and transparency." This shift is also visible in the documents of the Economic Council of the Finnish Government. To use Schmidt's words, ${ }^{42}$ these documents represent the "coordinative discourse" on Nordic openness, whereby the cognitive aspects of the policy prescriptions on transparency are communicated and shared among the policy actors. In order to legitimate the changes, the "communicative discourse" of Nordic openness evokes an invented tradition ${ }^{43}$ that accommodates and legitimizes the changes at hand.

\section{Conceptual Shifts in Government Platforms: Publicity, Openness, Transparency}

The shifts in the rhetoric of governing, i.e. arguments for its justification, are not only a reflection of the institutional state of affairs but also carry the potential for institutional change. These shifts can be seen to represent changes in the perceived responsibilities and goals of government. In institutional theory, an "ideational life-cycle" is often seen as consisting of periods of consensus, interrupted by an external shock or ideational uncertainty, during which change is possible or necessary. ${ }^{44}$ Once the ideational and normative consensus is again sought,

40 Kettunen, Globalisaatio ja Kansallinen Me: Kansallisen Katseen Historiallinen Kritiikki.

41 Tero Erkkilä and Ossi Piironen, Rankings and Global Knowledge Governance: Higher Education, Innovation and Competitiveness (New York, NY: Palgrave Macmillan, 2018).

42 Schmidt, "Discursive Institutionalism."

43 Hobsbawm, "Introduction: Inventing Traditions."

44 Cf. Marcussen, Ideas and Elites: The Social Construction of Economic and Monetary Union. 
that is as ideas become embedded or institutionalised, ${ }^{45}$ another stable period follows. Scholars have identified institutional change as an outcome of ideational and ideological change, also entailing political conflict. ${ }^{46}$ Here ideational change largely rests on shifts in political rhetoric and narratives. ${ }^{47}$

The discourse of "Nordic openness," a perception of Nordic institutional tradition that separates Finland from other nations, emerged in the 1990s, coinciding with the end of the Cold War, Finnish membership of the EU and financial crisis. This juncture allowed new institutional practices and ideas to be introduced into the Finnish model of governing. ${ }^{48}$ In Reinhart Koselleck's Begriffsgeschichte, such a critical juncture is termed Sattlezeit - a period of crisis during which new concepts emerge and old ones are critically altered. ${ }^{49}$ According to Koselleck, conceptual change occurs when the gap between our experiences (Erfahrungsraum) and future expectations (Erwartungshorizont) grows too large. ${ }^{50}$ It is here that the vocabulary tends to change, as actors need to re-conceptualise the new environment. Looking at the political concepts used in Finnish government platforms since the 1917, neither "publicity" nor "openness," let alone "transparency," have traditionally been part of the political vocabulary, but instead started to appear in the 1990s. This new discourse makes references to past traditions, such as the "principle of publicity."

Internationally, the adoption of information access laws has usually been preceded by a political debate on the topic, often crucial for the adoption. ${ }^{51}$ The term "publicity" did not appear in the Finnish government platforms at the time of adoption of the Act on the Publicity of Government Documents in 1951. There were hardly any references to "publicity" or "openness" before the 1990s, when the notion of "openness" started to appear in the government platforms of Prime Ministers Harri Holkeri (1987-1991), Esko Aho (1991-1995), Paavo Lipponen (1995-1999, 1999-2003), Anneli Jäätteenmäki (2003), Matti

45 Margaret R. Somers and Fred Block, "From Poverty to Perversity: Ideas, Markets, and Institutions over 200 Years of Welfare Debate,” American Sociological Review 70, no. 2 (2005): $260-87$.

46 Guy B. Peters, Jon Pierre, and Desmond S. King, “The Politics of Path Dependency: Political Conflict in Historical Institutionalism," The Journal of Politics 67, no. 04 (2005): 1275-1300, doi:10.1111/j.1468 -2508.2005.00360.x; Schmidt, The Futures of European Capitalism.

47 Schmidt, "Discursive Institutionalism”; Somers and Block, "From Poverty to Perversity,” 280. 48 Cf. Marcussen, Ideas and Elites: The Social Construction of Economic and Monetary Union; Peters, Pierre, and King, "The Politics of Path Dependency."

49 Koselleck, Futures Past; Melvin Richter, The History of Political and Social Concepts: A Critical Introduction (Oxford: Oxford University Press, 1995), 17.

50 Koselleck, Futures Past, 256.

51 Bennett, “Understanding Ripple Effects.” 
Vanhanen (2003-2007, 2007-2010), Mari Kiviniemi (2010 - 2011), Jyrki Katainen (2011-2014), Alexander Stubb (2014-2015), Juha Sipilä (2015-2019), Antti Rinne (2019) and Sanna Marin (2019-). ${ }^{52}$ At the turn of the 1990s, there was an apparent confusion between the concepts of "public" and "open" - the former referred to the public sector and government and the latter was understood in economic terms, as referring to "open," unregulated, sectors. The vocabulary then shifted, as "openness" gained democratic connotations such as "openness of governance." The economic connotations were associated with a new term, "transparency," which also introduced the idea that the government was responsible to the market.

In the government platform of Prime Minister Harri Holkeri (published in April 1987) there were no references made to "openness" with regard to responsible rule, but a reference was made to "open labour markets." Similarly, the platform of Prime Minister Esko Aho (1991) contained references to "openness" in the context of economy. The government platform of Paavo Lipponen (1995), titled "The government of employment and joint responsibility," mentioned functioning labour markets and labour market agreements as the keys to success. The "open" labour market deliberations became an element of national competitiveness. ${ }^{53}$

The democratic connotations of openness first started to appear systematically in 1995 in the context of European governance (Finland joined the EU in 1995). The first Lipponen government stated that Finland would "enhance the openness of the decision-making of the European Union," which became a legitimizing argument for Finnish accession to the Union. Openness remained a topic in Finnish EU politics in the platform of the second government of Paavo Lipponen (April 1999). The platform stated that the government would act so that the EU's decision-making and administration would be developed according to the principles of "openness," "responsibility," and "efficiency." At the same time, there were references to openness in relation to global economics and electoral funding. Transparency, a newcomer to the Finnish political vocabulary, appeared for the first time as "transparency" of pricing and financing in domestic politics.

At the same time, the institutional practices were in turmoil, as the relevant legislation was being updated and several policies were adopted. ${ }^{54}$ This led to the adoption of the Act on the Openness of Government Activities (1999), the Personal Data Act (1999), and the Administrative Procedure Act (2004). Indeed, the

52 The Finnish government platforms are all available online. Finnish Government, accessed 3 September, 2021, https://valtioneuvosto.fi/tietoa/historiaa/hallitusohjelmat.

53 Cf. Kettunen, "The Nordic Model and the Making of the Competitive 'Us.”'

54 Erkkilä, Government Transparency: Impacts and Unintended Consequences. 
legislation used up until this time was from 1951 and was even drafted before the Second World War (in 1939). Given the changes due to digitalisation of public administration alone, it is noteworthy that the revision took this long, particularly in a country that now identifies with openness so prominently.

The government platforms published in the 2000s continued the agenda, where the openness of decision making in the EU was a priority. While openness still received some mentions in the context of open markets, the economic connotations were mostly found under "transparency." The government platform of Antti Rinne (2019), taken over in turn by Sanna Marin and titled "Inclusive and Competent Finland," also aimed to enhance collaboration with other Nordic countries that arguably "share similar values concerning democracy, openness and welfare state."

To conclude, over the years the references to open government have emerged in the government platforms. "Openness" was first used as an antonym of "public" and started to obtain market connotations in the late 1980s. It was later displaced by the term "transparency," a newcomer to Finnish political vocabulary that now predominantly carries references to the market economy. The government discourse shifted from the semantic field of democracy towards the market. In government rhetoric, openness appeared as a state tradition that was also promoted in the EU, which appeared as the secretive "other" of the open Nordic countries such as Finland.

\section{Transparency and Economic Understanding of Openness}

The two debates around openness and transparency - the Finnish exceptional openness in the EU context (Nordic openness) and the economic potential of transparency - meet in a nationalistic discourse. The Finnish concern over the secretiveness of the EU in the mid-1990s initiated a narrative of openness as a Nordic tradition in Finnish governing, separating "us" from "them." National competitiveness, which openness and transparency are increasingly seen as enhancing, is also debated under the same logic of inclusion and exclusion: "our" competitive edge over "the others." The coupling of efficiency and economic performance with openness is a novel and not so readily apparent idea. In fact, in the past, mainstream economics assumed that open systems were less efficient than closed ones. ${ }^{55}$ This conceptual change in government vocabulary points to

55 Mark Skousen, “The Perseverance of Paul Samuelson's Economics,” Journal of Economic Perspectives 11, no. 2 (1997): 137-52. 
political innovation due to a paradigm change in economics, ${ }^{56}$ where the ideas of market efficiency increasingly build on transparency.

The emergence of new political concepts also entails political innovation and shifts in belief systems. ${ }^{57}$ Here the study of conceptual change and the historical analysis of institutions converge in their aim to reveal how social beliefs are formed and institutionalised. ${ }^{58}$ Conceptual change therefore gives an insight into why and how certain policy problems arise, how they are constructed, and how these problems can be arguably solved. Political concepts are means for governing and sudden referencing to a policy concept is an indication of active "politicking," making the issue politically "playable."59

In the early 2000s, institutional economics was a rising topic in economic policy-making, ${ }^{60}$ featuring also prominently in the reports of the Economic Council of the Finnish Government at that time. ${ }^{61}$ In these texts, the open market and the availability of information are seen as mutually reinforcing and the role of the state is perceived as enabling market activities. In the past, reference to the Nordic model had provided an argument for synchronisation with other Nordic countries and Sweden in particular. ${ }^{62}$ However, the debate on Nordic openness, despite its explicit referencing of "Nordicness," now marked the synchronization of Finnish institutional practices with transnational institutional models of transparency stemming from international organisations such as the

56 Stiglitz, "Information and the Change in the Paradigm in Economics."

57 James Farr, "Understanding Conceptual Change Politically," in Political Innovation and Conceptual Change, ed. Terence Ball, James Farr, and Russell L. Hanson (Cambridge: Cambridge University Press, 1989), 25; Skinner, "Language and Political Change,” 20.

58 Bo Rothstein and Sven Steinmo, ed., Restructuring the Welfare State: Political Institutions and Policy Change (New York: Palgrave Macmillan, 2002), 16.

59 Kari Palonen, "Four Times of Politics: Policy, Polity, Politicking, and Politicization," Alternatives 28, no. 2 (2003): 55; Skinner, "Meaning and Understanding in the History of Ideas."

60 Torben Iversen, "The Dynamics of Welfare State Expansion: Trade Openness, De-Industrialisation and Partisan Politics," in The New Politics of the Welfare State, by Paul Pierson (Oxford: Oxford University Press, 2001), 45-79; Ugo Pagano, "Economics of Institutions and the Institutions of Economics," in Transforming Economics: Perspectives on the Critical Realist Project, ed. Paul Lewis (London: Routledge, 2004), 252-67; Dani Rodrik, "Why Do More Open Economies Have Bigger Governments?” The Journal of Political Economy 106, no. 5 (1998): 997-1032.

61 Valtioneuvoston kanslia, "Euroopan Rakenteelliset Jäykkyydet," Valtioneuvoston kanslian julkaisusarja (Helsinki: Valtioneuvoston kanslia, 2002); Valtioneuvoston kanslia, "Osaava, Avautuva ja Uudistuva Suomi. Suomi Maailmantaloudessa -Selvityksen Loppuraportti,” Valtioneuvoston kanslian julkaisusarja (Helsinki: Valtioneuvoston kanslia, 2004).

62 Pauli Kettunen, "The Nordic Welfare State in Finland," Scandinavian Journal of History 26, no. 3 (September 1, 2001): 225 - 47, doi:10.1080/034687501750303864. 
World Bank and the OECD. ${ }^{63}$ This also entailed a shift in the self-understanding and narrative of Finland's place in the world.

During the Cold War Finland was seen as a gateway between East and West and references to "Nordic" democracy and society were used to highlight the fact that Finland was not part of the Eastern Bloc. ${ }^{64}$ The current references to Nordic openness indicate a repositioning, where Finland is portrayed as a member of a Nordic bloc within the EU but is also depicted as a leader in globalisation. The Nordic model is now closely linked to a discourse on national competitiveness and to a related pattern of identity, the competitive "us." 65 The global indicators have ranked Nordic countries high in competitiveness, democracy, and good governance, which are also linked to institutional traditions in education, gender equality, and welfare.

One of the institutional characteristics that stands out in global comparisons is the history of openness and access to government information. Transparency International's Corruption Perception Index (published in 1995) has ranked Finland and the other Nordic countries consistently within the top ten of least corrupt countries. While this ranking does not measure transparency but corruption - specifically bribery - it has been a source of great national pride in Finland that it is now arguably one of the most "open” and least corrupt countries in the world. Transparency is also implied in the World Economic Forum's Global Competitiveness Index (published in its current form since 2004) that focuses on the institutional determinants of national economic performance. The Nordic countries, Finland included, again rank well.

In 2006 the World Economic Forum found that the Nordic countries were among the most competitive in the world, due to virtuous circles of transparency and openness. Its chief economist and director of the Global Competitiveness Programme Augusto Lopez-Claros, stated in 2006:

In many ways the [Nordic countries] have entered virtuous circles where various factors reinforce each other to make them among the most competitive economies in the world. [...] These are also countries that have public institutions that are characterised by an exceptionally high level of transparency and openness and this has contributed to improve business confidence. ${ }^{66}$

63 Erkkilä, Government Transparency: Impacts and Unintended Consequences.

64 Kettunen, "The Nordic Welfare State in Finland," 234.

65 Kettunen, "The Nordic Model and the Making of the Competitive 'Us."”

66 Augusto Lopez-Claros, The Global Competitiveness Report 2005-2006: Video Interviews, Augusto Lopez-Claros, http://www.weforum.org/en/initiatives/gcp/GCR20052006VideoInterviews/ index.htm. 
Together with the Finnish success in the OECD's PISA ranking, which depicted Finnish primary education as a global leader and a model for others to follow, these indicators have further contributed to the discourse of Nordic openness that builds on an imaginary of global competitiveness and is used to construct the notion of the competitive "us." 67 Indeed, one of the mechanisms through which global indicators become effective is "subjectification," where actors acquire patterns of identities linked to proposed action to maintain competitiveness. ${ }^{68}$ While the storyline is not always clear, there is a shared understanding of the positive qualities of openness and transparency that carry the promise of a governance system that is at the same time democratic and efficient. Effectively, transparency becomes a "third term" ${ }^{69}$ which allows the bypassing of dichotomies such as democracy/efficiency, public/private, market/hierarchy (bureaucracy); instead of either-or, it promises both.

\section{The Open and Direct Finn: Anders Chydenius and Global Economy}

During the 2000s, the perception of “openness" as a Finnish historical trait grew. The positive portrayal of Finland in the governance indices provided social scientific proof for the narrative adopted earlier. This narrative also offered Finland a new self-image, bearing connotations of progress and modernity, which also lent credibility to Finnish attempts to export and promote institutional openness elsewhere. In 2006, Finland named a "transparent and effective Union" as its objective for its EU presidency, highlighted also in the transparent logo of the presidency. The theme was based on Finnish identity of being "open" and "direct" as well as "progressive."70 Here we again see the dialectic between democracy (open) and efficiency (direct).

In Finnish political architecture the issue of transparency had become topical earlier in the construction of the Finnish Parliament supplementary building, completed in May 2004. Even though the proposal that won the bid for the construction project did not go particularly far in utilising glass materials, the vast majority of the proposals submitted in 1999 proposed that glass was a

67 Kettunen, Globalisaatio ja Kansallinen Me. Kansallisen Katseen Historiallinen Kritiikki.

68 Erkkilä and Piironen, Rankings and Global Knowledge Governance.

69 Bob Jessop, "The Rise of Governance and the Risks of Failure: The Case of Economic Development', "International Social Science Journal 155 (1998): 29-45.

70 Finnish EU Precidency 2006, [http://www.eu2006.fi/]. 
symbol of the "principle of publicity." While transparent architecture in political buildings was in fashion at the time, ${ }^{72}$ the metaphor of transparency ${ }^{73}$ is now linked with a historical tradition of openness in Finland.

The narrative of openness has even entered historical inquiry. This is most obvious in the historical accounts of Anders Chydenius, who together with his peer Peter Forsskål has attracted international interest. ${ }^{74}$ Behind Chydenius's ideas on freedom of print and the right of acquiring information on state matters was his opposition to the mercantilist tradition in eighteenth-century Sweden, embodied in Stockholm's trade privileges over peripheries. In Finland, historians have drawn attention to the "Finnish" roots of this eighteenth-century thinker, but at the same time used Chydenius to highlight the Swedish lineages of the Finnish state, sharing a legal and administrative tradition. ${ }^{75}$ The historical accounts of Chydenius and his "Nordic" legacy hence stress Finland's history as part of Sweden, but at the same time portray Finland as a periphery, and a nation to come, struggling against Stockholm.

71 Eduskunta, "Lisärakennuksen arkkitehtuurikilpailu” (Eduskunta, 1999).

72 Deborah Ascher Barnstone, The Transparent State: Architecture and Politics in Postwar Germany (New York: Routledge, 2005); Nigel Whiteley, "Intensity of Scrutiny and a Good Eyeful: Architecture and Transparency," Journal of Architectural Education 56, no. 4 (2003): 8-16, doi:10.1162/104648803321672915.

73 William Whyte, "How Do Buildings Mean? Some Issues of Interpretation in the History of Architecture," History and Theory 45, no. 2 (2006): 153-177, doi:10.1111/j.14682303.2006.00355.x.

74 John M. Ackerman and Irma E. Sandoval-Ballesteros, "The Global Explosion of Freedom of Information Laws," Administrative Law Review 58, no. 1 (2006): 85-130; Hood, “Transparency in Historical Perspective.," 8; Stephen Lamble, “Freedom of Information, a Finnish Clergyman's Gift to Democracy,” Freedom of Information Review 97, no. February 2002 (2002): 2 - 8; Ulla Carlsson and David Goldberg, ed., The Legacy of Peter Forsskål: 250 Years of Freedom of Expression (Gothenburg: Nordicom, University of Gothenburg, 2017), https://www.nordicom.gu.se/sv/system/tdf/publikationer-hela-pdf/the_legacy_of_peter_forsskal._250_years_of_freedom_of_expression.pdf?file $=1 \&$ type $=$ node $\& i d=38645 \&$ force $=0$.

75 Jyrki Käkönen, “Anders Chydenius ja 1700-Luvun Suomalainen Valtio-Opillinen Ajattelu,” in Valtio Ja Yhteiskunta: Tutkielmia Suomalaisen Valtiollisen Ajattelun ja Valtio-Opin Historiasta, ed. Jaakko Nousiainen and Dag Anckar (Juva: Werner Söderström, 1983), 46-49; Manninen, "Anders Chydenius and the Origins of World's First Freedom of Information Act”; Ilkka Patoluoto, "Hyödyllinen Luomakunta: Hyötyajattelun Maailmankuvalliset Perusteet 1700-Luvun Ruotsin Valtakunnassa," in Hyöty, Sivistys, Kansakunta: Suomalaista Aatehistoriaa, ed. Juha Manninen and Ilkka Patoluoto (Oulu: Kustannusosakeyhtiö Pohjoinen, 1986); Virrankoski, Anders Chydenius: Demokraattinen Poliitikko Valistuksen Vuosisadalta. 
In his writings Chydenius portrays the "free state" or "free nation" not as an enemy of libertarian freedoms, but rather as their keeper. ${ }^{76}$ When describing the state, he uses metaphors such as a "ship," "body," or "clock," which describe the state as an intact entity, in need of "steering" and "well-performing" components. ${ }^{77}$ Chydenius argued for a widening of political inclusion, for which information on state matters was a necessity. The state was to inform its citizens about its successes and misfortunes alike so that they would know the "truth." It was in the search for truth that Chydenius saw the rationality of governance based on the "free state."78 The truth was to be sought by an exchange of ideas and opinions and Chydenius encouraged his readers to engage in public debates. ${ }^{79}$ These debates he saw as ideally taking place through writing. The results of this "competition of pens" were to be spread across the nation through the new printing technique. ${ }^{80}$

A symbolic figure in Finland, his face on the old 1000 Finn Mark note, Chydenius is often seen as a father of Finnish state theoretical thinking, ${ }^{81}$ a Nordic Adam Smith or an interpreter of Montesquieu. ${ }^{82}$ Even though Anders Chydenius himself regarded his work for the liberalising of print as his major achievement, ${ }^{83}$ it took future generations some 240 years to take an interest in this. Since the early 2000s, Chydenius has appeared in the speeches and public appearances of Finnish politicians. ${ }^{84}$ Chydenius's ideas are now seen as a Finnish "export product." 85 Swedish politicians have also made claims for this thinker, but it turns out that his legacy is less known in Sweden than in Finland. In

76 Anders Chydenius, "Den nationala vinsten," in Politiska skrifter af Anders Chydenius (Helsinki: G. W. Edlunds förlag, 1880), 31.

77 Chydenius, 31.

78 Chydenius, 31.

79 Chydenius, Valitut Kirjoitukset (Porvoo: Werner Söderström, 1929), 170.

80 Chydenius, "Den nationala vinsten," 31.

81 Käkönen, "Anders Chydenius ja 1700-Luvun Suomalainen Valtio-Opillinen Ajattelu.”

82 Kimmo Sarje, “Anders Chydenius - Montesquieun Ihailija,” Politiikka 4 (1979): 297-304.

83 Chydenius, Valitut Kirjoitukset, 434-37.

84 Tuija Brax, "Julkisuusperiaatteen Haasteet." (Tietämisen vapauden päivän seminaari, Puhe tietämisen vapauden päivän seminaarissa, November 30, 2007), http://www.om.fi/Etusivu/Ajankohtaista/Ministerinpuheita/Puhearkisto/Puheet2007Brax/1196159328843; Tarja Halonen, Puhe Anders Chydeniuksen juhlavuoden pääjuhlassa Kokkolassa 1.3.2003, Anders Chydenius Säätiö, 2005) (speech at the main celebration of the Anders Chydenius Jubilee Year); Jacob Söderman, "Salailusta on Tullut Maan Tapa," Helsingin Sanomat, November 19, 2006, https://www.hs.fi/ sunnuntai/art-2000004441307.html; Jacob Söderman, "On Transparency” (presentation, IIAS conference, Monterrey, Mexico, July 16, 2006).

85 Manninen, “Anders Chydenius and the Origins of World's First Freedom of Information Act," 16. 
2009, a Finnish delegation delivered a portrait of Chydenius to Anders Borg, the Swedish Minister of Finance, who wanted to have Chydenius on the wall of his office, because no picture of Chydenius could be found in Sweden. ${ }^{86}$ This shows how Chydenius has been reinvented for political use.

In Chydenius's home region of Ostrobothnia, the issue of accessing state information had arisen in the tar export trade, as revenues were channelled to the ruling elite in Stockholm rather than to local tradesmen. Anders Chydenius wanted accurate information on the sales that the mercantilist rule of Stockholm was making at the expense of the local tar producers and also the uprooting of corruption was seen to play a role. ${ }^{87}$ Ostrobothnia, on the west coast of modernday Finland, was the biggest manufacturer of tar and Sweden's wealthiest region, but it lacked the rights to export tar independently. This now provides an analogy for contemporary globalization, ${ }^{88}$ just as the rise of printing technology in the eighteenth century is a fitting metaphor for the current issues of digitalisation and the internet. The ideas of Chydenius are seen as relevant in the contemporary context, especially when analysing the global transformations in trade and democracy, where openness and transparency are coupled with ideas of low corruption, rule of law, democracy, and competitiveness.

Chydenius and his ideas have great metaphoric value, making him appear as a forbear of the contemporary problem of joining global trade and democracy. His historical legacy can with good reason be described as "multipurpose."89 The different readings of Chydenius have also sparked debates on his political use. ${ }^{90}$ Chydenius is either a Finn battling against the Swedes ${ }^{91}$ or a SwedishFinn, ${ }^{92}$ a construct used in Finnish history when referring to Finland under

86 Kalle Koponen, "Talouspappi Chydenius Pääsi Valtiovarainministerin Seinälle Ruotsissa,” Helsingin Sanomat, 9 January, 2009.

87 Juha Manninen, “Anders Chydenius and the Origins of World's First Freedom of Information Act," in The World's First Freedom of Information Act: Anders Chydenius' Legacy Today, ed. Anders Chydenius Foundation (Kokkola: Anders Chydenius Foundation, 2006), 18-53; Pentti Virrankoski, Anders Chydenius: Demokraattinen Poliitikko Valistuksen Vuosisadalta (Juva: Werner Söderström, 1986), 109.

88 Halonen, Puhe Anders Chydeniuksen juhlavuoden pääjuhlassa Kokkolassa 1.3.2003

89 Pauli Kettunen, "Yhteiskunta Ohjattavana ja Ohjaajana - Historiallinen Näkökulma: Monikäyttöinen Chydenius,” Anders Chydenius foundation, accessed 3 September, 2021, http:// www.chydenius.net.

90 Henrikki Heikka, "Kokkolan Kirkkoherra Parantaa Terroristit," Kosmopolis 34, no. 1 (2004): 63-68; Jyrki Käkönen, "Henrikki Heikka Chydeniuksesta, Terrorismin Parantamisesta ja Vapaakaupasta,” Kosmopolis 34, no. 1 (2004): 111-14.

91 Heikka, "Chydeniuksesta, Vapaasta Kaupasta ja Terrorismista”; Käkönen, "Henrikki Heikka Chydeniuksesta, Terrorismin Parantamisesta ja Vapaakaupasta."

92 Brax, "Julkisuusperiaatteen Haasteet”; Söderman, "Salailusta on Tullut Maan Tapa." 
Swedish rule. In his time, Chydenius regarded himself as a Swede. ${ }^{93}$ He did talk about the prosperity of "Finns" under the Swedish King, but his understanding of this was mostly regional, limited to Ostrobothnia and Åbo. ${ }^{94}$

There is a tendency for historical references to political theorists to often become mixed with contemporary political concepts and arguments. These theorists become part of a political debate or ideological grouping that they, in their time, would never have recognised. ${ }^{95}$ Because of his influence on liberalising print, which also came to result in the abolition of absolutist secrecy, Chydenius is now portrayed as the father of the "Freedom of Information Act" 96 or the "right to know," both concepts of Anglo-American origin. Chydenius is also seen as a forbear of "free trade" or the abolition of "trade barriers." 97 The "principle of publicity" becomes translated into the "principle of transparency" and the high ranking of the Nordic countries in the Transparency International's Corruption Perception Index is seen as a legacy of Chydenius. ${ }^{98}$ The principle of publicity has become a Finnish invention that has spread as far as Nokia and the sauna. ${ }^{99}$ A recent English translation of Ander Chydenius's texts carries the title "Anticipating the Wealth of Nations," linking Chydenius to Adam Smith. ${ }^{100}$ However, Skinner highlights the importance of understanding ideas in their context, and argues that such anticipations are mostly unwarranted in conceptual history. ${ }^{101}$

Chydenius stands as a historical reference point in a time when the relations of centre and periphery were being rethought. A vigorous opponent to mercantilism, Chydenius easily gets drawn into debates where notions of (neo) mercantilist and (neo) liberalist viewpoints meet. Even the Finnish narratives and im-

93 Chydenius, Valitut Kirjoitukset, 426.

94 Juha Manninen, Valistus ja Kansallinen Identiteetti: Aatehistoriallinen Tutkimus 1700-Luvun Pohjolasta (Helsinki: Suomalaisen Kirjallisuuden Seura, 2000), 43; compare Manninen, "Anders Chydenius and the Origins of World's First Freedom of Information Act"; Jouko Nurmiainen, "Particular Interests and the Common Good in Swedish Mid-18th-Century Diet Politics: The 'Finnish' Perspective,” Scandinavian Journal of History 32, no. 4 (2007): 388-404, doi:10.1080/ 03468750701659350.

95 Skinner, "Meaning and Understanding in the History of Ideas."

96 Manninen, “Anders Chydenius and the Origins of World's First Freedom of Information Act." 97 Heikka, "Chydeniuksesta, Vapaasta Kaupasta ja Terrorismista."

98 Söderman, "On Transparency."

99 Manninen, “Anders Chydenius and the Origins of World's First Freedom of Information Act," 17.

100 Anders Chydenius, Anticipating the Wealth of Nations: The Selected Works of Anders Chydenius, 1729-1803, ed. Maren Jonasson and Pertti Hyttinen (London: Routledge, 2011).

101 Skinner, "Meaning and Understanding in the History of Ideas." 
ages carrying a collective memory of openness contain a dialectic between democracy (open) and efficiency (direct). Though the storyline is not always fully explicit, there are references to global markets and globalisation and the role of information in organising them.

However, the present concerns of globalisation were beyond the reach of this eighteenth-century thinker. The references to Chydenius and his work are part of the politically motivated uses of the normatively appealing concepts of openness and transparency. ${ }^{102}$ The narrative of Chydenius and other references to history become part of the "communicative discourse" of Nordic openness, ${ }^{103}$ which now also accommodates the new ideas on transparency that have become internationally diffused. Leaping over history, Chydenius has become the embodiment of the "open and direct Finn": Nordic, educated, incorruptible, and engaged in trade.

\section{Conclusions}

To sum up, the policy discourse on openness has resonated particularly well with the Finnish institutional context, where the legislation on accessing government information and the principle of publicity has existed for a long time (see Table 1). Since the mid-1990s the discourse of Nordic openness has appeared in Finnish government platforms and bills, in policy documents and strategies, in public speeches of politicians, and in narratives told by civil servants. ${ }^{104}$ It is also found in governance indices and their interpretations, contemporary historical analyses, and even in architecture and design of political relevance. The cognitive aspects of this new policy discourse tap into the social scientific perceptions of governance, and institutional and information economics. The normative, legitimating discourse of Nordic openness extends to Finnish national history, inventing a tradition of Nordic governing. The notion of "Nordic" openness is convenient here, as it portrays Finns as members of a particularly open society as opposed to other nationalities, but at the same time also references the fact that Finland was a part of Sweden prior to 1809, highlighting and co-opting the Swedish institutional practices that exist in Finland and that are now drawing global attention. Furthermore, this (Nordic) discourse also bypasses the era of Russian rule in Finland (1809-1917), characterised by censorship.

102 Skinner, "Language and Political Change."

103 Schmidt, "Discursive Institutionalism."

104 See also Erkkilä, Government Transparency: Impacts and Unintended Consequences. 
Table 1. Ideational dimensions of the discourse on openness and their representations in Finland $^{105}$

\begin{tabular}{|c|c|c|c|}
\hline & Form & Ideational core & Representations \\
\hline Cognitive & $\begin{array}{l}\text { legislative reform, policy } \\
\text { on public sector informa- } \\
\text { tion, administrative ethics } \\
\text { reform, initiatives of public } \\
\text { hearings, accountability } \\
\text { reform, better regulation } \\
\text { programme }\end{array}$ & $\begin{array}{l}\text { new social scientific per- } \\
\text { ceptions of governance, } \\
\text { institutional and infor- } \\
\text { mation economics }\end{array}$ & \multirow{2}{*}{$\begin{array}{l}\text { government platforms, } \\
\text { government bills, policy } \\
\text { documents, strategies, } \\
\text { public speeches, public } \\
\text { programmes, numbers (in- } \\
\text { dices, rankings), narratives } \\
\text { of civil servants, contem- } \\
\text { porary historical analysis, } \\
\text { political architecture and } \\
\text { design }\end{array}$} \\
\hline Normative & $\begin{array}{l}\text { Nordic openness, the open } \\
\text { and direct Finn }\end{array}$ & $\begin{array}{l}\text { Openness as a Nordic } \\
\text { tradition of Finnish gov- } \\
\text { erning }\end{array}$ & \\
\hline
\end{tabular}

The shifting belief systems among policy actors carry new cognitive aspects but this is largely hidden in the normatively appealing talk on openness as a tradition. Because institutional openness has a long history as a virtue of the Enlightenment, the Nordic welfare state, and liberalism, the new connotations seem to find an ideational root in the above philosophies. In the era when the Finnish welfare state was built, the exchange of information and negotiations between various groups were an underlying and unspoken norm of governing. ${ }^{106}$ Amid economic globalisation, "openness," "public sector information," and "transparency" become political and economic concerns that are actively governed. History is therefore not only a marker for institutional continuity but also carries a potential for institutional change.

Though the above developments in political rhetoric are seemingly independent of institutional affairs, they converge in the rationalities and mechanisms of change. The shift in the political rhetoric and concepts of governing not only reflects institutional change but also propels it. In terms of accountability, the shift in conceptualisation reframes the mechanism of government control. This also points to new external demands and audiences to whom civil servants bear responsibilities. Somewhat paradoxically, the sudden awareness of a democratic trajectory marks an opening for its reframing in economic terms.

Consequently, the openness of government activities has become part of a new political imaginary of national competitiveness. There is a perceivable reassessment of the responsibilities of the government, marking a new ideational

105 After Schmidt, The Futures of European Capitalism, 214.

106 Kettunen, "The Nordic Model and the Making of the Competitive 'Us."” 
cycle: Finnish governments now increasingly bear responsibilities towards market actors through openness and transparency ${ }^{107}$ Though the democratic connotations of openness would intuitively imply greater government responsibility towards citizens, the emergence of this discourse coincides with mounting demands for Finland's competitiveness in an open economy.

Comparing the relevant policy documents with the public speeches of politicians, one can identify cognitive and normative aspects in the discourse of openness that are in dissonance, though economic aspects are also slowly entering the normative talk on openness. There is an apparent construction of the collective memory of openness as a Nordic tradition of Finnish governing. This is part of Finland's new European identity. The historical aspects are also prominently present in the coordinative discourse shared by policy actors. The discourse on Nordic openness is a local variant of the global discourse on transparency. While references to institutional history allow it to contain a nationalistically appealing normative message, the cognitive aspects of this discourse are increasingly linked to global economic competitiveness. This invented tradition now also concerns Anders Chydenius, who has become the embodiment of the "open and direct" Finn.

107 Cf. Marcussen, Ideas and Elites: The Social Construction of Economic and Monetary Union. 